\title{
Osmotic Pump Extended Release Dosage
} Form

National Cancer Institute

\section{Source}

National Cancer Institute. Osmotic Pump Extended Release Dosage Form. NCI

Thesaurus. Code C42760.

A solid designed to release active and/or inert ingredient(s) at a controlled, prolonged rate so as to reduce dosing frequency, based on osmotic pressure between the inside of the dosage form and the external environment. 